\title{
Mesafeli Sözleşmelerin Kurulmasına Aracılık Edenlerin Tüketici Hukuku Bağlamında Sorumluluğunun Belirlenmesi*
}

\author{
Selin SERT SÜTÇÜ \\ Doç. Dr., Akdeniz Üniversitesi, Hukuk Fakültesi, Medeni Hukuk Anabilim Dal1, selin81hukuk@gmail.com, (Sorumlu \\ Yazar / Corresponding Author)
}

\begin{tabular}{|c|c|}
\hline Makale Bilgileri & Öz \\
\hline $\begin{array}{l}\text { Anahtar Kelimeler: } \\
\text { Tüketici, Mesafeli } \\
\text { sözleşme, Aracılık, } \\
\text { Sorumluluk, } \\
\text { Tüketicinin korunması. }\end{array}$ & $\begin{array}{l}\text { Mesafeli sözleşmeler, } 6502 \text { Sayılı Tüketicinin Korunması Hakkında Kanun'un m.48 hükmünde ve } \\
\text { aynı zamanda Mesafeli Sözleşmeler Yönetmeliği kapsamında ayrıntılı olarak düzenlenmiş ve hüküm } \\
\text { altına alınmıştır. COVID-19 süreci ile birlikte mesafeli sözleşmeler, hayatımızın ayrılmaz bir parças1 } \\
\text { haline gelmiştir. Mesafeli sözleşmelerin sklıkla tercih edilmesinin sebebi; bu sözleşmelerin tüketiciler } \\
\text { tarafından çok vakit harcamadan, oturdukları yerde, birden çok seçenek arasından kolaylıkla seçim } \\
\text { yapmasına imkân sağlamasıdır. Bu sözleşmelerde tüketicilerin paylaştıları bilgilerinin kötüniyetli } \\
\text { üçüncü kişilerin eline geçme ihtimalinin olması, tüketicilerin kişisel verilerinin korunması gerekliliği } \\
\text { de mesafeli sözleşmelerin riskleridir. Mesafeli sözleşmeler, çoğunlukla satıcı ile tüketicinin aracılar } \\
\text { vasıtasıyla bir araya geldiği sözleşmelerdendir. Mesafeli sözleşmelerin Elektronik Ticaretin } \\
\text { Düzenlenmesi Hakkında Kanun kapsamında da düzenlenmiş olması sebebiyle, bu kanun } \\
\text { hükümlerinde düzenlenen aracılık edenler kavramıyla, TKHK kanun kapsamında düzenlenen aracılık } \\
\text { edenler kavramının benzer, farklı yönleri de çalışmamızda incelenecektir. Aracılık etme kavramının } \\
\text { ne olduğu, yasal mevzuat içerisinde ne şekilde düzenlendiği ve aracıların tüketicilere karş1 } \\
\text { sorumluluğu belirlenmeye çalış1lacaktır. }\end{array}$ \\
\hline
\end{tabular}

\section{Determining The Liability of Those Who Intermediate in The Establishment of Distance Agreements in The Context of Consumer Law}

\begin{tabular}{|c|c|}
\hline Article Info & Abstract \\
\hline $\begin{array}{l}\text { Article History } \\
\text { Received: 16.05.2021 } \\
\text { Accepted: } 23.06 .2021 \\
\text { Published: } 25.06 .2021 \\
\text { Keywords: } \\
\text { Consumer, Distance } \\
\text { Contract, Mediation, } \\
\text { Responsibility, } \\
\text { Consumer protection. }\end{array}$ & $\begin{array}{l}\text { Distance contracts are regulated and taken under the provisions of article } 48 \text { of the Law on the } \\
\text { Protection of the Consumer No. } 6502 \text { and also within the scope of the Regulation on Distance } \\
\text { Contracts. With the COVID- } 19 \text { process, distance contracts have become an integral part of our lives. } \\
\text { The reason why distance contracts are often preferred; These agreements allow consumers to easily } \\
\text { choose from among multiple options at their place of residence, without wasting much time. The } \\
\text { possibility of the information shared by the consumers in these contracts falling into the hands of } \\
\text { malicious third parties and the necessity of protecting the personal data of consumers are also the risks } \\
\text { of distance contracts. Distance contracts are mostly contracts where the seller and the consumer come } \\
\text { together through intermediaries. Since distance contracts are also regulated within the scope of the } \\
\text { Law on the Regulation of Electronic Commerce, similar and different aspects of the concept of } \\
\text { intermediaries regulated in the provisions of this law and the concept of intermediaries regulated under } \\
\text { the TKHK law will be examined in our study. It will be tried to determine what the concept of } \\
\text { intermediation is, how it is regulated in the legal legislation and the responsibility of intermediaries } \\
\text { towards consumers. }\end{array}$ \\
\hline
\end{tabular}

Atıf/Citation: Sert Sütçü, S. (2021). "Mesafeli Sözleşmelerin Kurulmasına Aracılık Edenlerin Tüketici Hukuku Bağlamında Sorumluluğunun Belirlenmesi”, Necmettin Erbakan Üniversitesi Hukuk Fakültesi Dergisi, 4(1), s. 276-287.

Plagiarism: Bu makale intihal programında taranmış ve en az iki hakem incelemesinden geçmiştir. // This article has been scanned via a plagiarism software and reviewed by at least two referees.

\footnotetext{
* Bu makale 10-12 Nisan 2021 tarihinde Uluslararası Necmettin Erbakan Hukuk Kongresi’nde sunulan özet bildirinin genişletilmiş halidir.
} 


\section{GíRiș}

Teknoloji ve pazarlama tekniklerinin gelişmesi, uzaktan pazarlama yöntemiyle mal teslimi veya hizmet sağlanması, satıcı ve sağlayıcılar tarafından tüketicilere ulaşma amacıyla kullanılan yöntemler çeşitlilik kazanmıştır ${ }^{1}$.

Tüketiciler ile satıcı ve sağlayıcıların fiziki olarak karşı karşıya gelmeksizin uzaktan iletişim araçlarıyla sözleşme kurmaları tercih edilen bir yöntem haline gelmiştir ${ }^{2}$. Tüketiciler tarafından en çok tercih edilen yöntemlerden birisi de mesafeli sözleşmelerdir. Satıcı/sağlayıcının mesafeli sözleşme kurmaları ve aracılardan yararlanmalarının hem faydaları hem de riskleri bulunmakla birlikte, tüketicilerin bu sözleşmeyi tercih etmeleri sebebiyle çeşitli koruma yöntemlerinin geliştirilmesi de gerekmektedir.

Çalışmamızda mesafeli sözleşme kavramı, bu sözleşmelerin faydaları/riskleri, mesafeli sözleşmelerde aracı kavramı ile mesafeli sözleşmelerde aracıların sorumluluğu anlatılacaktır.

\section{MESAFELİ SÖZLEŞME KAVRAMI}

Mesafeli sözleşmeler; 6502 Sayılı Tüketicinin Korunması Hakkında Kanun’un m. 48 hükmünde düzenlenmiştir. Kanun koyucu bu düzenlemede mesafeli sözleşmelerin tanımına yer vermiştir. Söz konusu tanıma göre; "satıcı veya să̆layıcı ile tüketicinin eş zamanlı fiziksel varlı̆̆ olmaksızın, mal veya hizmetlerin uzaktan pazarlanmasına yönelik olarak oluşturulmuş bir sistem çerçevesinde, taraflar arasında sözleşmenin kurulduğu ana kadar ve kurulduğu an da dâhil olmak üzere uzaktan iletişim araçlarının kullanılması suretiyle kurulan sözleşmeler” mesafeli sözleşme olarak nitelendirilmiştir.

Kanundaki tanımdan bir sözleşmenin mesafeli sözleşme ${ }^{3}$ olarak nitelendirilmesi açısından bazı unsurlara ${ }^{4}$ sahip olması gerektiği sonucuna ulaşılmaktadır ${ }^{5}$. Bu unsurlar;

-iletişim araçlarının kullanılması suretiyle sözleşme yapılması,

-uzaktan pazarlama sisteminin varlığı,

-tüketici ile satıcı veya sağlayıcının bir araya gelmemesi,

-tarafların anlaşmasıdır.

\footnotetext{
${ }^{1}$ Demir, Mehmet. Mesafeli Sözleşmelerin İnternet Üzerinden Kurulması, 1. Baskı, Turhan Kitabevi, Ankara, 2004, s.16; Aslan, Yılmaz. 6502 sayılı Kanuna Göre Tüketici Hukuku, 4.Bask1, Ekin Yayınevi, İstanbul, 2014,s. 479.

${ }^{2}$ Erten, Alev. Türk ve Alman Hukukunda Mesafeli Sözleşmeler (Avrupa Topluluğu Mesafeli Sözleşmeler Direktifi ile Karşılaştırmalı Olarak), Banka ve Ticaret Hukuku Araştırma Enstitüsü Yayınları, Ankara, 2004, s.11 vd.; Demir. s.14 vd.; Aslan. s. 479 vd.

${ }^{3}$ TKHK dışında 6098 Sayılı Türk Borçlar Kanunu'nda mesafeli satış kavramına yer verilmiştir. TBK anlamında mesafeli satışın söz konusu olması için; satıcı veya sağlayıcının sözleşme konusunu bir yerden başka bir yere göndermesi halinde söz konusu olmaktadır. TBK mesafeyi malın gönderilmesi ve sözleşmenin ifası kavramlarıyla ilişkilendirmektedir. TKHK anlamında mesafeli satış ise tüketici ile satıcı veya sağlayıcının eş zamanlı fiziksel ortamda bir araya gelmemesini ifade etmektedir. Tüketici satıcı veya sağlayıcı ile birlikte olmadığı için de sözleşme iletişim araçları vasıtasıyla yapılmaktadır.

${ }^{4}$ Kara, İlhan. Yeni Kanuna Göre Tüketici Hukuku, 1. Bask1, Ankara, 2015, s. 1015 vd.

${ }^{5}$ Zevkliler, Aydın/Özel, Çağlar. Tüketicinin Korunması Hukuku, 1. Baskı, Seçkin Yayıncılık, Ankara, 2016, s. 322 vd.; İlgün, Candaş. Tüketicinin Korunması Hakkında Kanun Açıklamalı Gerekçeli, 2. Baskı, Adalet Yayınevi, Ankara, 2015, s. 199.
} 
6098 Sayılı Türk Borçlar Kanununda yer alan "mesafeli satış” kavramıyla, TKHK da düzenlenen "mesafeli sözleşme” farklı kavramlardır. TBK'ya göre mesafeli satış sözleşmesi; satılan malın normal olarak sözleşmenin ifa yerinden başka bir yere gönderilmesidir yani buradaki mesafe kavramıyla malın gönderilmesi ya da sözleşmenin ifası anlatılmak istenmektedir. TKHK anlamında mesafeli sözleşmeyse, tüketiciyle mal ya da hizmet sağlayıcısının aynı yerde olmamasını, aralarında mesafe olmasını ve bu sebeple sözleşmenin uzaktan iletişim araçlarıyla yapılmasıdır ${ }^{6}$. Mesafeli sözleşme; sözleşme yapılması tekniğidir ${ }^{7}$. Satış, kira vb. gibi farklı sözleşmeler de mesafeli sözleşme yoluyla yapılabilmektedir ${ }^{8}$. Hangi sözleşmelerin mesafeli sözleşme yoluyla yapılamayacağı da Mesafeli Sözleşmeler Yönetmeliği'nde düzenlenmiştir9'

Mesafeli sözleşmelerin aynı zamanda Mesafeli Sözleşmeler Yönetmeliğinde de TKHK'a benzer şekilde tanımlandığı görülmektedir. Mesafeli sözleşmelerin 6563 Sayılı Elektronik Ticaretin Düzenlenmesi Hakkında Kanun bakımından da değerlendirilmesi gerekmektedir. ETDHK tüm elektronik satışlar $1^{10}$ kapsamına almış ve elektronik satışlarda sözleşme taraflarını satıcı/sağlayıcı ve alıcı olarak belirlemişken, TKHK sözleşme taraflarını satıc1/sağlayıcı ve tüketici olarak belirlediği için TKHK daha dar kapsamlıdır. O sebeple tüketiciler açısından bir hüküm olan hususlarda TKHK hükümlerinin, herhangi bir hüküm olmayan hallerde ise ETDHK hükümlerinin uygulanması gerekmektedir.

Mesafeli sözleşmelerde taraflardan birisi tüketici, diğer taraf ise satıcı veya sağlayıcıdır. Satıcı veya sağlayıcı ile tüketicinin bir araya gelmesini sağlayan aracı kavramı kanunda nasıl ve ne şekilde tanımlanmıştır hususunu değerlendirmeden önce mesafeli sözleşmelerin faydaları ve riskleri üzerinde durulması gerekmektedir.

\section{MESAFELİ SÖZLEŞMELERIN FAYDALARI VE RİSKLERİ}

Mesafeli sözleşmeler; COVID-19 süreci ile birlikte hayatımızın adeta merkez kavramı haline gelen ve gündelik hayatta en çok tercih ettiğimiz sözleşme türlerinden birisi olarak karşımıza çıkmaktadır. Bu süreçte sağlık, hijyen vb. nedenlerle tüketicilerin mesafeli sözleşmeleri daha çok tercih ettiği görülmektedir ${ }^{11}$.

Mesafeli sözleşmelerin tercih nedenlerinden bir diğeri tüketicinin bulunduğu ortamı terk etmeden kolaylıkla aynı veya benzer nitelikteki mal veya hizmet çeşitliliği arasından kendi istek ve arzusuna en uygun olanını seçme imkânına sahip olmasıdır. Kalite, ucuzluk ve nitelik

\footnotetext{
${ }^{6}$ Topaloğlu, Mustafa. "Madde-48, Mesafeli Sözleşmeler”, Milli Şerh, 1. Baskı, Aristo Yayınevi, İstanbul, 2016, s.762.

${ }^{7}$ Uzun Kazmac1, Özge. "İnternet Üzerinden Kurulan Mesafeli Sözleşmelerde Tüketicinin Korunması", Marmara Üniversitesi Hukuk Araştırmaları Dergisi, C.22, S.3, 2016, s.2793; Gezder, Ümit. "Mesafeli Sözleşmeler", Yeni Tüketici Hukuku Konferansı (Ed. Murat İnceoğlu), 1. Baskı, On İki Levha Yayıncılık, İstanbul, 2015, s. 334; İnceoğlu, Murat/Baş Süzel, Ece. "Mesafeli Sözleşme Kurulmasına Aracılık Edenlerin Tüketiciye Karşı Sorumluluğu", Bahçeşehir Üniversitesi Hukuk Fakültesi Dergisi, C.15, S. 189-190, 2020, s. 476.

${ }^{8}$ Kanun koyucu Mesafeli Sözleşmeler Yönetmeliği m.2 hükmünde mesafeli sözleşmelerin konusu olamayacak sözleşmeleri belirlemiştir. $\mathrm{O}$ halde bu hükümde belirtilen istisnalar dışında satıcı veya sağlayıcı mesafeli sözleşme yapabilecektir.

${ }^{9}$ Mesafeli Sözleşmeler Yönetmeliği m.2.

${ }^{10}$ Elektronik sözleşmeler hakkında ayrıntılı bilgi için bkz. Sağlam, İpek. Elektronik Sözleşmeler, 1. Baskı, Legal Yayınc1lık, İstanbul, 2007.

${ }^{11}$ Alabay, M. Nurettin. "Geleneksel Pazarlamadan Yeni Pazarlama Yaklaşımlarına Geçiş Süreci”, Süleyman Demirel Üniversitesi İktisadi ve İdari Bilimler Fakültesi Dergisi, 2010, C. 15, S. 2 s. 214.
} 
bakımından daha kaliteli olma hususları da tüketici tercihlerini etkilemektedir. Bu durum aynı zamanda tüketicinin zamandan da tasarruf etmesini sağlayacaktır ${ }^{12}$.

Mesafeli sözleşmelerin tüketici açısından riskleri; tüketicinin çok fazla düşünme ve değerlendirme firsatı olmadan mal veya hizmeti satın almasıdır. Satıcı veya sağlayıcı konusundaki bilgisizlik, yanlış bilgi, malın iadesi veya cayma hakkı kullanılması konusundaki sıkıntılar da ne yazık ki beraberinde gelmektedir.

\section{MESAFELİ SÖZLEŞMELERDE ARACI KAVRAMI}

Mesafeli sözleşmelerde sözleşmenin tarafları; satıcı/sağlayıcı veya tüketici de olsa mesafeli sözleşmelerde tüketici ile satıcı/sağlayıcının bir araya gelmesini sağlayan, mal veya hizmetlerin uzaktan pazarlanmasını sağlayan sistemi kuran aracılar vardır. Aracılar; tüketicinin mesafeli sözleşmelerde satıcı ile sağlayıcıyla bir araya gelmesini sağlayarak, sözleşmenin kurulmasını sağlamaktadır.

Satıcı veya sağlayıcının aracı aracılığıyla sözleşme yapmak istemesinin farklı sebepleri olabilecektir. Örneğin; çok bilinmeyen bir markanın sattığı malların veya sunduğu hizmetlerin tüketici tarafından aracının sunduğu uzaktan pazarlama yöntemiyle tüketiciyle satıcı ve sağlayıcının buluşmasını sağlayabilecektir. Tüketici satıcı veya sağlayıcının sattığı mallar veya sunduğu hizmetler hakkında bilgi sahibi olacak, böylece çevresindeki kişilere o mal veya hizmetle ilgili tavsiyelerde bulunarak, diğer tüketiciler tarafından malın veya hizmetin tercih edilmesini sağlayabilecektir.

Mesafeli sözleşmelerin kurulmasına aracılık edilmesi kavramı; ne TKHK ne de Mesafeli Sözleşmeler Yönetmeliğinde tanımlanmamıştır. TKHK ve Mesafeli Sözleşmeler Yönetmeliği birlikte değerlendirildiğinde aracı kavramının uzaktan pazarlamaya yönelik sistemi kuran, uzaktan iletişim araçları vasıtasıyla sözleşmenin kurulmasını sağlayanlar olarak nitelendirilebilecektir.

Satıcı veya sağlayıcıya uzaktan pazarlamaya yönelik olarak kurduğu bu sistemi kullandıran aracı; ya satılan tek bir üründen ya da aylık, yıllık gibi tamamen tarafların özgür iradeleri ile belirleyecekleri bir bedeli ödemelidir.

Elektronik Ticaretin Düzenlenmesi Hakkında Kanun m.2/d hükmünde; “Aracı hizmet sağlayıcı: Başkalarına ait iktisadi ve ticari faaliyetlerin yapılmasına elektronik ticaret ortamını sağlayan gerçek ve tüzel kişiler” olarak belirtilmiştir. O halde aracı; gerçek veya tüzel kişi olabilecektir. Aracının satıcı veya sağlayıcı ile tüketici arasında adeta bir köprü vasıtası görevini üstlendiği söylenebilecektir. Uzaktan pazarlama yönteminin hangi özelliklere sahip olması gerektiğine dair bir düzenleme bulunmamaktadır.

\footnotetext{
${ }^{12}$ Gezder, Ümit. Mukayeseli Hukuk Açısından İnternette Akdedilen Sözleşmelerde Tüketicinin Korunması, 1. Baskı, Beta Yayınları, İstanbul, 2004, s. 53.
} 


\section{SATICI/SAĞLAYICI İLE TÜKETICI VE ARACI ARASINDAKİ HUKUKI İLISSKININ BELIRLENMESI}

Mesafeli sözleşmeler TKHK m.48 hükmünde düzenlenmiştir. Kanun koyucu m.48 hükmünde herhangi bir ayrım yapmadığı için; sözleşmenin konusu hem mal ${ }^{13}$ hem de hizmet ${ }^{14}$ olabilecektir. Mesafeli sözleşme, TKHK kapsamında düzenlendiği için sözleşmenin bir tarafı tüketici, diğer tarafı ise satıcı veya sağlayıcı olacaktır. TKHK m.48 hükmündeki mesafe kavramının bir sözleşme yapma türü olduğunu, yani satıcı veya sağlayıcının eş zamanlı fiziksel varlığı olmadan yapılan sözleşmeyi ifade ettiğini, satıcı veya sağlayıcı ile tüketicinin mesafeli olarak satış, kira vb. sözleşmeler yapabileceği ancak uygulamada mesafeli sözleşmelerin çoğunlukla satış sözleşmesine konu edindiğini söyleyebiliriz. Tüketici ile satıcı/sağlayıcı arasındaki satış sözleşmesine öncelikle olarak TKHK, hüküm bulunmayan hallerde ise TBK m.207 vd. satış sözleşmesine ilişkin hükümler uygulanacaktır.

Satıcı/sağlayıcı ile aracı arasındaki sözleşme iş görme sözleşmesidir. İş görme sözleşmesi kapsamında aracının kurduğu sistem sayesinde tüketiciye malın veya hizmetin tanıtılması ve böylece satılması amaçlanmaktadır. Tüketiciye, aracı, uzaktan iletişim vasıtaları kullanarak, satıcının malını veya sağlayıcının sunacağı hizmeti tanıtmakta böylece satıcı/sağlayıcı ile tüketicinin arasında sözleşme kurulmasını sağlamaktadır. Aracı tüketici tercihlerine göre tüketicinin satın almak istediği mal veya hizmetleri tüketiciye alternatifler halinde göstermekte, tüketici istediği satıcıyı, kalite, fiyat, nitelikleri belirlemek suretiyle satış sözleşmesini satıcı veya sağlayıcı ile akdetmektedir.

Aracı ile tüketici arasında üyelik sözleşmesi yapılmaktadır ${ }^{15}$. Tüketici adres, telefon gibi iletişim bilgilerini aracı ile paylaşarak, bu bilgilerin aracının alt yapısında saklanmasına müsaade etmektedir. Aracı tüketiciye ait bilgilerin saklanması aşamasında tüketiciden herhangi bir ücret almamaktadır. Aracı tüketicinin şahsi bilgilerini, ödeme bilgilerini alt yapı sisteminde saklama yükümlülüğü altındadır. Tüketicinin daha önce satın aldığı mallara ilişkin kayıtların tutulması ve daha sonraki alışverişler için tüketici tercihlerinin belirlenmesi de aracının tüketiciye sunduğu hizmetlerdir. Tüketicinin kişisel verilerinin de bu anlamda korunması önemlidir. Aracı, tüketicinin kişisel verilerini de saklamakla yükümlüdür. Kişisel verilerin korunması konusunda Kişisel Verilerin Korunması Kanunu ${ }^{16}$ hükümlerinden yararlanılacaktır.

Aracı ile tüketici arasında bu üyelik sözleşmesi dışında herhangi bir sözleşme yoktur. TKHK m. 48/5 hükmünde "aracılık edenler, satıcı veya sağlayıcı ile yaptıkları sözleşmeye aykırı fiillerinden dolayı sorumludur" düzenlemesi gereğince; aracılık edenlerin sorumluluğu sadece satıc1/ sağlayıcıya karşı gibi görünse de aracıların tüketiciye karşı sorumluluğun olup olmadığının belirlenmesi önemlidir. Birçok tüketici aracıya güvenerek sözleşme yapmayı tercih etmektedir.

\footnotetext{
${ }^{13}$ Tüketicinin Korunması Hakkında Kanun m.3/h hükmünde mal, alışverişe konu olan; taşınır eşya, konut veya tatil amaçlı taşınmaz mallar ile elektronik ortamda kullanılmak üzere hazırlanan yazılım, ses, görüntü ve benzeri her türlü gayri maddi malları ifade eder.

${ }_{14}$ TKHK m.3/d hükmünde hizmet; Bir ücret veya menfaat karşılı̆̆ında yapılan ya da yapılması taahhüt edilen mal sağlama dışındaki her türlü tüketici işleminin konusunu ifade etmek için kullanılmaktadır.

15 İnceoğlu/Baş Süzel. s. 478.

16 Tüketicilerin kişisel verilerinin korunması hakkında ayrıntılı bilgi için bkz. Keser, Yıldırım. "Tüketicilerin Kişisel Verilerinin İşlenmesinde Açık Rıza”, Selçuk Üniversitesi Hukuk Fakültesi Dergisi, C.28, S.3, 2020, s. 1181 vd.
} 
Örneğin; "hepsi burada, trendyol" gibi aracıların ${ }^{17}$ güvenilir olduğunu düşünen ve bu düşünceyle sözleşme yapan tüketici, satıcı veya sağlayıcıya ulaşamasa dahi ayıplı bir mal söz konusu olduğunda aracının da bu ayıptan sorumlu olacağı düşüncesiyle hareket etmektedir. Çalışmamızın bundan sonraki kısmında mesafeli sözleşmelerde aracının sorumluluğu hem tüketiciye karşı hem de satıc1/sağlayıcıya karşı sorumluluk olmak üzere ayrı ayrı incelenecektir.

\section{MESAFELİ SÖZLEŞMELERDE ARACILARIN SORUMLULUĞU}

Mesafeli sözleşmelerde aracıların sorumluluğuna ilişkin düzenleme TKHK m.48/5 hükmüdür. Söz konusu hükme göre aracıların sorumluluğunun belirlenmesi bakımından aracıların tüketiciye karşı sorumluluğunun ayrı, aracıların satıcı/sağlayıcıya karşı sorumluluğunun ayrı ve son olarak aracının hem aracı hem de satıcı/sağlayıcı durumunda olduğu hallerde tüketiciye karşı sorumluluğunun ayrıca incelenmesi gerekmektedir.

\section{A. SATICI/SAĞLAYICININ AYNI ZAMANDA ARACI OLARAK TÜKETICIYYE KARŞI SORUMLULUĞU}

Son dönemlerde aracıların kendi markalarını kurup, kendi kurdukları sistem içerisinde kendi mal ve hizmetlerini tüketiciye sattığı veya sunduğu görülmektedir. Bu durumda aracı, aynı zamanda satıc1/sağlayıcı konumundadır.

Aracının hem satıc1/sağlayıcı hem de aracı olduğu durumlarda tüketiciye karşı sorumluluğu satıcının ve sağlayıcının sorumluluğu ile aynı şekilde değerlendirilmelidir. Satıcının/sağlayıcının mal/hizmetin ayıplı olmasından, zamanında teslim/ifa edilmesinden dolayı tüketiciye karşı sorumluluğu TKHK ve TBK anlamında söz konusu olacaktır.

Aracının satıc1/sağlayıcı olması, aracının tüketiciye ait bilgileri saklama, istenildiğinde üçüncü kişilerle paylaşma yükümlülüğünü ortadan kaldırmamakta aksine burada aracının sorumluluğu genişlemiş olmaktadır. Aracının TKHK m.48 ve Mesafeli Sözleşmeler Yönetmeliği kapsamındaki sorumluluğu dışında bir de satıcı/sağlayıcı olarak sorumluluğu devam etmektedir.

\section{B. ARACININ SATICIYA/SAĞLAYICIYA KARŞI SORUMLULUĞU}

Aracının satıc1/sağlayıcı ile yapmış olduğu sözleşmeyle aracı, tüketici ile satıcı/sağlayıcının kendi oluşturduğu sistem çerçevesinde pazarlanmasını sağlamaktadır. Bu pazarlama ise satıı/sağlayıcı ile aracı arasındaki sözleşmesinin niteliğine göre aylık, yıllık, satılan mal veya sunulan hizmet adedine göre belirlenebilecektir.

Tüketicinin Korunması Hakkında Kanun m. 48/5 hükmünde "aractlı edenler, satıcı veya sağlayıcı ile yaptıkları sözleşmeye ayktrı fillerinden dolayı sorumludur" düzenlemesi gereğince; aracı satıcı/sağlayıcıyla yapmış olduğu sözleşmeye uygun davranmak zorundadır. Sözleşmeye aykırlık, mal/hizmetin sürekli olarak temin edilmemesi, mal/hizmetin ayıplı ifası şeklinde olabileceği gibi aracının oluşturduğu sistemden yararlanan satıcı/sağlayıcının sistemi kullanma bedelini ödememesi gibi de söz konusu olabilecektir. Sözleşmeye aykırı hareket edilmesi durumunda, meydana gelen zararların tazmin edilmesi gerekmektedir.

17 Yüce, Melek Bilgin. "E-Ticarette Ayıplı Mal/Hizmet Alan Tüketicinin Haklarl ve Bu Hakların Yöneltileceğgi Muhataplar”, E-Ticaret, 1. Bask1, Aristo Yayınları, İstanbul, 2017, s. 264. 
Mesafeli Sözleşmeler Yönetmeliği m. 20 hükmü gereğince; “Oluşturdukları sistem çerçevesinde, uzaktan iletişim araçlarını kullanmak veya kullandırmak suretiyle satıcı veya sağlayıcı adına mesafeli sözleşme kurulmasına aracılık edenler, bu Yönetmelikte yer alan hususlardan dolayı satıcı veya sağlayıcı ile yapılan işlemlere ilişkin kayıtları üç yıl boyunca tutmak ve istenilmesi halinde bu bilgileri ilgili kurum, kuruluş ve tüketicilere vermekle yükümlüdür” . Söz konusu düzenleme gereğince; aracılık edenler, satıcı/sağlayıcıyla yapılan işlemlere ilişkin kayıtları üç yıl boyunca tutmakla yükümlüdür ${ }^{18}$. Bu bilgilerin güvenilir ortamda saklanması, özellikle kişisel verilerin ihlal edilmemesi önemlidir. Sistem alt yapısı içerisinde bilgilerin saklanması aracının sorumluluğundadır. Kişisel verilerin ihlali halinde oluşan zarardan da aracı; satıcı/sağlayıcıya karşı sorumludur ${ }^{19}$.

Elektronik Ticaretin Düzenlenmesi Hakkında Kanun'da elektronik ticarete ilişkin düzenlemelerle birlikte; elektronik sözleşmelere ilişkin bilgi verme yükümlülükleri, ticari iletişim, hizmet sağlayıcı ve aracı hizmet sağlayıcıların sorumlulukları, kişisel verilerin korunması ve uygulanacak yaptırımlar düzenlenmiştir. Bu kanundaki ilgili hükümler, tüketici işlemi olsun olmasın genel olarak elektronik ortamda yapılan sözleşmeleri kapsamaktadır.

\section{ARACILARIN TÜKETICIYY KARŞI SORUMLULUĞU}

Aracıların, TKHK m.48/5 anlamında tüketicilere karşı sorumluluğu bulunmaktadır. $\mathrm{Bu}$ sorumlulukla ilgili olarak doktrinde baskın görüşs ${ }^{20}$; aracıların da satıcı/sağlayıcıdan tüketiciden bedel tahsis etmeleri sebebiyle, tüketiciye karşı satıcı/sağlayıcı gibi sorumlu olmaları gerektiğidir. Aracının, tüketiciden bedel tahsis etmesinin sebebi; satılan malın/sunulan hizmetin bedelinin satıcı/sağlayıcı adına oluşturulan sistem çerçevesinde alınarak, satıcıya/sağlayıcıya verilmesidir. $\mathrm{Bu}$ tahsis, satıcı/sağlayıcının adına ve hesabına bedel tahsisi olduğu için, temsil ilişkisi söz konusudur. Temsilcinin sözleşmeden kaynaklanan sorumluluğu TBK anlamında düzenlenmemiştir. $\mathrm{O}$ halde aracının temsilci olarak hareket ettiği, bedel tahsis ettiği durumda tüketiciye karşı her anlamda sorumlu olduklarının kabul edilmesi mümkün değildir.

Doktrinde aracıların TKHK m.48 hükmü kapsamında sorumlu tutulmalarının bir diğer sebebi olarak; TKHK m.3 hükmü gösterilmektedir ${ }^{21}$. TKHK m.3 hükmünde tanımlanan satıc1 ve sağlayıcı ifadelerinde geçen "kamu tüzel kişileri de dahil olmak üzere ticari veya mesleki amaçlarla hareket eden veya mal satanın adına ya da hesabına hareket eden gerçek veya tüzel kişi" şeklinde bir belirleme yapılmış olması sebebiyle, ifadede geçen adına ya da hesabına hareket etmeyle temsil ilişkisinin işaret edildiği belirtilmiştir. Kanaatimizce; bu düşünceye iki sebepten dolayı katılmak mümkün görünmemektedir. Kanun koyucu m.3 hükmünde satıcı veya sağlayıcıyı tanımlarken kullandığı adına ve hesabına hareket etme satıcının/sağlayıcının temsilcisi olarak

\footnotetext{
${ }^{18}$ Çabri. s. 769.

19 “Yemek sepeti olarak tüketicilere hizmet veren her türlü yemek/yiyecek-içecek temini için farklı satıcı/sağlayıcılarla tüketicinin buluşmasını sağlayan aracı, 27.03.2021 tarihinde kendi oluşturduğu uzaktan pazarlama sistemi içerisinde tüketicilere ait olan kişisel verilerin çalındığını duyurdu. Yemek sepeti çalınan bilgilerin kredi kartlarına ilişkin olmadığının, kredi kartlarına ilişkin bilgilerin kendi altyapıları içerisinde saklanmadığının altını çizdi”" https://www.hurriyet.com.tr/gundem/yemeksepetindeki-bilgilerin-calinmasi-kullanicilar-icin-ne-anlama-geliyor41774405, E.T.: 05.05.2021.

${ }^{20}$ Aydoğdu, Murat. Tüketici Hukuku Dersleri, 1. Bask1, Adalet Yayınevi, Ankara, 2015, s. 290; Çabri, Sezer. Tüketicinin Korunması Hakkında Kanun Şerhi, 1. Baskı, Adalet Yayınevi, Ankara, 2016, s. 770; Topaloğlu, s.775.

${ }^{21}$ Çabri. s. 770.
} 
hareket eden ve temsilcisi olarak sorumlu tutulanların kapsamını belirlemek için getirilen bir düzenlemedir. Satıcı/sağlayıcının sorumluluğu tüketiciye karşı nasıl düzenlenmişse, satıcı/sağlayıcının temsilcisi durumunda olanların da aynı şekilde sorumlu olmaları gerekmektedir. Aracıların satıcı ve sağlayıcıya karşı satıı1/sağlayıcı olarak sorumlu olmaları sadece aracının aynı zamanda satıcı/sağlayıcı olarak kabul edildiği durumlar için geçerli olmalıdır. Diğer sebep ise kanun koyucunun m.3 anlamında satıcı/sağlayıcının temsilcisini de tüketiciye karşı sorumlu olduğunu düzenlemesi, tüketiciye karşı sorumlu olacakların genişletilmesi amacı taşımaktadır. Kanun koyucu TKHK m.48 hükmünde ayrıca aracı kavramına yer verdiği için, aracının satıcı/sağlayıcının temsilcisi olması veya temsilcisi olarak düşünülmesi mümkün değildir.

Aracıların satıcı veya sağlayıcının sözleşmeye aykırı davranışlarından dolayı tüketiciye karşı sorumlu olmamaları, bir an için bir kusursuz sorumluluk halinin söz konusu olduğunu akla getirse de kusursuz sorumluluk hallerinin kanunda özel olarak düzenlenmiş olması zorunluluğu karşısında bu sonuca da ulaşmak çok mümkün görünmemektedir ${ }^{22}$.

Aracıların tüketiciye karşı sorumluluğunun belirlenmesi bakımından kanımızca, TKHK m.48/5 hükmüne ve Mesafeli Sözleşmeler Yönetmeliğine bağlı kalınması kanunun ve yönetmeliğin bu anlamda madde metnine bağlı kalarak yorumlanması gerekmektedir.

Aracıların mesafeli sözleşme yapılmasında bedeli tahsil edip, tüketicinin cayma hakkını kullanma süresi boyunca mal/hizmet bedelini satıcıya/sağlayıcıya ödememesi, tüketicinin cayma hakkını kullanmaması halinde ise tahsil ettiği bedeli satıcıya/sağlayıcıya vermesi, tüketicinin cayma hakkını kullanma hakkının olduğu süre boyunca bu bedeli kullanması halinde; satıcının/sağlayıcının temsilcisi olarak hareket ettiği düşünülse dahi, kanımızca aracının satıcı/sağlayıcının tüketiciye gönderdiği malı, sunduğu hizmeti kontrol etme ve bu anlamda sorumluluğuna gidilmesi mümkün olmayacaktır. Aracı; tüketiciye gönderilen malın, sunulan hizmetin ayıplı olup, olmadığını, zapttan dolayı sorumluluğun söz konusu olup olmayacağını bilme imkânına sahip olmadığından aracının sorumluluğunun dar yorumlanması, TKHK m.48/5 ve Mesafeli Sözleşmeler Yönetmeliği hükümlerine bağlı kalınması gerekmektedir.

Tüketicinin Korunması Hakkında Kanun m.48/5 hükmünde aracıların sorumluluğu;

"- kayıtların tutulması, istenilmesi halinde bu bilgileri ilgili kurum, kuruluş ve tüketicilere vermekle yükümlü oldukları",

"- satıcı ve sağlayıcı ile yaptıkları sözleşmeye aykırı fillerden dolayı sorumludurlar" düzenlemesi gereğince, ilk cümlede bahsedilen sorumluluğun sınırlarının çizilmesi kolaydır. Buna göre; aracıların mesafeli sözleşmelerin yapılmasından önce tüketiciye verilen ön bilgilendirme formunun verilmesi aracının ilk sorumluluğudur. Ön bilgilendirme formunun uzaktan iletişim aracıyla tüketiciye verilmesi, tüketicinin bu bilgilendirme formunu okuduğunun, anladığının uzaktan iletişim aracına uygun olarak tüketici tarafından onaylandığının satıcı/sağlayıcıya bildirilmesi aracıların sorumluluğundadır.

Aracı; satıcı/sağlayıcıyla yaptığı sözleş̧me gereğince tüketiciden bedel tahsil etme yetkisine sahipse, tüketicinin cayma hakkını kullanmasına/kullanmamasına bağl olarak bu bedeli depo etme

22 İnceoğlu/Baş Süzel. s. 481. 
veya satıcı/sağlayıcı hesabına aktarmalıdır. Bu durumda tüketici cayma süresi içinde cayma hakkını kullanırsa, sözleşme konusu mal/hizmetin bedeli aracı tarafından tüketiciye ödenmelidir.

Aracı; satıc1/sağlayıcıyla yaptığı sözleşmeyle tüketiciden bedel tahsil etmiyorsa, bedel tahsilinden dolayı tüketiciye ve satıcı/sağlayıcıya karşı sorumlulukları bulunmamaktadır.

Aracıların bedel tahsil etmeleri sırasında bankaların güvenlik sistemlerini kullanmaları sık karşılaşılan bir durumdur. Aracının bedel tahsiline ilişkin kredi kartı ve ödeme yöntemlerine ilişkin korumayı kendi uzaktan pazarlama sisteminin banka ya da kredi kuruluşları tarafından kullanımına izin verdiği durumlarda, tüketicinin kredi kartı veya ödeme yöntemine ilişkin paylaştığı bilgilerin üçüncü kişiler tarafından kötüye kullanılması halinde bu paylaşımın sebebinin tespit edilmesi önemlidir. Aracının kurduğu sistemden kaynaklanan sebeple, tüketicinin kredi kartı veya ödeme yöntemi bilgilerinin kötü niyetli üçüncü kişilerin eline geçmesi halinde aracının tüketiciye karşı sorumlu olacağı açıktır. Kredi kuruluşları veya bankanın, aracının kurduğu uzaktan pazarlama sistemine müdahale etme imkânının olduğu, bu sebeple kredi kartı bilgilerinin, ödeme yöntemlerinin kötü niyetli üçüncü kişiler tarafından kullanılması durumunda sorumluluk; bankaya veya kredi kullandıran kuruluşa ait olacaktır.

Aracılar, kurdukları sistem dâhilinde tüketicilere ait kişisel bilgileri uzaktan pazarlama sistemi içerisinde saklamak, tüketici aynı uzaktan pazarlama yöntemini kullanmak istediğinde bilgilerinin saklandığı bir depolama sistemine sahiptir. Aracının tüketiciye karşı bir başka sorumluluğu, bu depolama sisteminin korunmasını sağlamaktır.

Mamak İlçe Tüketici Hakem Heyetinin 19.12.2018 tarihinde verdiği kararında; bir internet sitesi üzerinden bir adet "drone" satın alan bir tüketicinin, satı̧s sözleşmesinin kurulmasından sonra mal tedarik aşamasındayken, satışın iptal edilerek tüketiciye bedelin iade edildiği, malın kendisine ödediği bedel karşıllı̆ı teslim edilmesi için başvuru yapmış, aracı malın bedelinde hata yapıldığı savunmasında bulunmuş, hakem heyeti hatalı bedel üzerinden tüketiciye malın satılması gerektiğgine hükmetmiştir. Aracının; Ankara 6. Tüketici Mahkemesine başvurusu üzerine mahkeme, 2019/16 Esas ve 2021/63 sayılı Kararında; emsal fiyatlara göre malın piyasa fiyatının neredeyse yüzde doksan indirimli satıldığını, satıcı/sağlayıcının mal bedelinde indirim yaptığına dair bir bilginin söz konusu olmadığı, mal bedelinin hata sebebiyle yanlış olduğunu, bu bedel üzerinden tüketiciye o malın satılmasının mümkün olmadığını ifade ederek, hakem heyetinin kararını bozmuştur ${ }^{23}$.

İzmir 3. Tüketici Mahkemesi 2019/111 Esas, 2019/580 Karar say1l kararındaysa; mal bedelinin benzer şekilde neredeyse yüzde doksan beşe yakın indirimli olarak sistemsel bir hata sebebiyle satın alınması durumunda, hakem heyetinin kararının doğru olduğuna ürün bedelinin sistemsel hatayla düşük gösterilmesi halinde malın belirtilen bedel üzerinden tüketiciye satılması gerektiğine karar vermiştiir ${ }^{24}$.

Kanımızca, aracının hata sebebiyle mal bedelini yanlış göstermesi durumunda hayatın olağan akışına göre malın o bedel üzerinden satılıp satılmayacağının tespit edilmesi gerekmektedir. Malın o bedelle satılacağına veya indirim yapılacağına dair bir bildirim yoksa

\footnotetext{
${ }^{23}$ www.uyap.gov.tr, E.T.: 14.05.2021.

${ }^{24}$ www.uyap.gov.tr, E.T.: 14.05.2021.
} 
sadece tüketicinin değil satıc1/sağlayıcının da korunması önemlidir. O sebeple malın hatalı bedel üzerinden satılması mümkün değildir.

Aracıların sorumluluğunun TKHK m.48/5 anlamında değerlendirildiğinde; ön bilgilendirme formu hazırlanması, bu formun tüketici ile paylaşılması, tüketicinin bilgilendirildiğinden satıcı/sağlayıcının haberdar edilmesi, kişisel verilerin saklanması, depo edilmesi ve bu bilgilerin Mesafeli Sözleşmeler Yönetmeliği hükümleri de dikkate alınarak saklanmasıdır. Sorumluluğun genişletilmesi madde hükmünün amacına aykırılık teşkil edecektir.

Tüketicinin Korunması Hakkında Kanun'un ceza hükümlerini içeren m.77/1 hükmünde, TKHK'nun m.48 hükmüne aykırılık halinde idari para cezası yaptırımı uygulanacağı düzenlendiğinden ve m.48 hükmünde satıcı veya sağlayıcı adına üç yıl boyunca belgelerin saklanması yükümlülüğü bulunmadığından, yalnızca satıcı veya sağlayıcı adına mesafeli sözleşme kurulmasına aracılık edenlere karşı idari para cezası yaptırım uygulanabilecektir.

Son olarak incelenmesi gereken husus; aracıların TKHK dışında bir sorumluluklarının söz konusu olup olmayacağı meselesidir. Aracıların, tüketiciye karşı satıc1/sağlayıcının mal/hizmetiyle ilgili ayrıca sorumluluk üstlendiğinin tüketici tarafından düşünüldüğü dolayısıyla dürüstlük kuralı gereğince tüketicilerde bir güven oluşturduğu durumlarda bu güvenden dolayı sorumlu olması gerektiği sonucuna ulaşılmalıdır. Güven sorumluluğunun ${ }^{25}$ geniş yorumlanmaması, tüketicinin satıcı/sağlayıcı ile aracının ayırt edilebildiği her durumda güven sorumluluğu hükümlerinin uygulanmaması gerekmektedir. Aracılık edenlerin güven sorumluluğu gereğince sorumlu tutulabildiği hallerde, ayıp, zapt, yararın ve hasarın geçişi gibi hususlarda satıc1/sağlayıcıyla müteselsil sorumlu olduğu sonucuna ulaşılması gerekmektedir.

Aracı; tüketiciye ait ad-soyad, adres, kredi kartı bilgileri ile bilgilerin uzaktan pazarlama yöntemi içerisinde saklanmasından, bu bilgilerin üçüncü kişilerle paylaşılmamasından dolayı sorumludur. Bu sorumluluk, Kişisel Verilerin Korunması Kanunu kapsamında olacaktır.

Elektronik Ticaretin Düzenlenmesi Hakkında Kanun ve Elektronik Ticarette Hizmet Sağlayıcı ve Aracı Hizmet Sağlayıcılar Hakkında Yönetmelik hükümleri incelendiğinde; aracıların sorumluluğunun internet sitesinin kurulması, aracıların hangi bilgileri sunması gerektiği gibi konularda sınırlı şekilde düzenlendiğinin kabul edilmesi gerekmektedir.

\section{SONUÇ}

Mesafeli sözleşmeler, tüketicinin oturduğu yerden kolaylıkla yapabildiği, aynı anda birden çok mal/hizmete ilişkin seçeneklere ulaşma imkânının olması sebebiyle çok tercih edilmektedir. Tüketicinin düşünme imkânı olmadan, çok çabuk bu sözleşmeleri yapabiliyor olması, mesafeli sözleşmelerde kişisel verilerin paylaşılması, ödeme yöntemlerine ilişkin olarak kredi kartı bilgilerine erişim imkânının olması gibi riskler ise mesafeli sözleşmeler yapılması konusunda tüketicileri düşündürmektedir.

Mesafeli sözleşmelerde aracılar; uzaktan pazarlama sistemlerinin kullanılması amacıyla tüketicilerle satıcı/sağlayıcının sözleşme yapmasını sağlayanlar olarak nitelendirilmiş, ancak

\footnotetext{
${ }^{25}$ Ayrıntılı bilgi için bkz. Kalkan Oğuztürk, Burcu. Güven Sorumluluğu, 1. Baskı, Vedat Kitabevi, İstanbul, 2008; Durak, Yasemin. "Güven Sorumluluğu ve Culpa In Contrahendo", Selçuk Üniversitesi Hukuk Fakültesi Dergisi, C.25, S.1, 2017.
} 
TKHK da aracıların ne tanımına ne de tüketiciye karşı ne şekilde sorumlu olacaklarına dair hükümlere açıkça yer verilmemiştir.

Aracıların sorumluluğuna ilişkin düzenleme TKHK m.48/5 hükmüdür. Söz konusu düzenlemeye göre; satıcı veya sağlayıcı ile yapılan işlemlere ilişkin kayıtları tutmak ve istenilmesi hâlinde bu bilgileri ilgili kurum, kuruluş ve tüketicilere vermekle yükümlüdür. Ayrıca bu fikra kapsamında aracılık edenler, satıcı veya sağlayıcı ile yaptıkları sözleşmeye aykırı fiillerinden dolayı sorumludur.

Aracıların sorumluluğunun anlaşılabilmesi için; aracıların aynı zamanda satıcı/sağlayıcı olması; aracıların satıcı/sağlayıcıya karşı sorumluluğu, aracıların tüketiciye karşı sorumluluğunun ayrı ayrı incelenmesi gerekmektedir. Aracı aynı zamanda satıc1/sağlayıcı ise bu durumda tüketiciye karşı satıcı/sağlayıcı gibi ayıptan, zapttan, yarar ve hasardan dolayı sorumlu olmalıdır. Aracıların, satıcı/sağlayıcıya karşı sorumluluğu aracıların satıcı/sağlayıcıyla yaptıkları sözleşme gereğince sözleşmeye aykırı fillerinin tamamından sorumludurlar. Aracıların uzaktan pazarlama sisteminden satıcı/sağlayıcının yararlanmasını sağlaması karşılığında aylık, yıllık veya satılan mal ya da sunulan hizmet için ayrı bir komisyon almak suretiyle satıcı/sağlayıcıyla sözleşme yaptıkları görülmektedir ${ }^{26}$. Aracıların tüketiciye karşı sorumluluğu ise tüketiciler ile aracıların yapmış oldukları üyelik sözleşmesiyle belirlenmektedir. $\mathrm{Bu}$ sözleşmeyle tüketicilerin sözleşme yapılmadan önce bilgilendirilmesi, tüketicilere ilişkin kayıtların tutulması ve bu kayıtların istenildiği zaman verilmesidir.

Aracıların tüketicilere ait kişisel verilere ilişkin kayıtları tutması sebebiyle kanımızca kişisel verilerinin korunması konusunda da ayrıca KVKK hakkında sorumlulukları söz konusu olabilecektir.

Aracıların tüketiciye karşı sorumluluğuna ilişkin bir diğer düzenleme; Elektronik Ticaretin Düzenlenmesi Hakkında Kanun'dur. Aracıların sorumluluğu internet sitesinin kurulması, aracıların hangi bilgileri sunması gerektiği gibi konularla sınırlı şekilde düzenlendiği, ancak TKHK kapsamında sadece tüketicilerin ETDHK kapsamında ise elektronik ticaret yapan tüketici olsun olmasın aracıların sorumluluğu düzenlenmiştir.

Aracıların tüketiciye karşı sorumlu oldukları son hal; dürüstlük kuralı gereğince tüketicilerde bir güven oluşturduğu durumlarda bu güvenden dolayı sorumlu olması gerektiği hususudur. Güven sorumluluğunun geniş yorumlanmaması, tüketicinin satıcı/sağlayıcı ile aracının ayırt edilebildiği her durumda güven sorumluluğu hükümlerinin uygulanmaması gerekmektedir. Aracılık edenlerin güven sorumluluğu gereğince sorumlu tutulabildiği hallerde, ayıp, zapt, yararın ve hasarın geçişi gibi hususlarda satıc1/sağlayıcıyla müteselsil sorumlu olduğu sonucuna ulaşılması gerekmektedir.

\footnotetext{
${ }^{26}$ İnceoğlu/Baş Süzel. s. 479.
} 


\section{KAYNAKÇA}

Alabay, M. Nurettin. "Geleneksel Pazarlamadan Yeni Pazarlama Yaklaşımlarına Geçiş Süreci”, Süleyman Demirel Üniversitesi İktisadi ve İdari Bilimler Fakültesi Dergisi, 2010, C. 15, S. 2.

Aslan, Yılmaz. 6502 sayılı Kanuna Göre Tüketici Hukuku, 4.Baskı, Ekin Yayınevi, İstanbul, 2014.

Aydoğdu, Murat. Tüketici Hukuku Dersleri, 1. Baskı, Adalet Yayınevi, Ankara, 2015. 2016.

Çabri, Sezer. Tüketicinin Korunması Hakkında Kanun Şerhi, 1. Baskı, Adalet Yayınevi, Ankara,

Demir, Mehmet. Mesafeli Sözleşmelerin Internet Üzerinden Kurulması, 1. Baskı, Turhan Kitabevi, Ankara, 2004.

Durak, Yasemin. "Güven Sorumluluğu ve Culpa In Contrahendo", Selçuk Üniversitesi Hukuk Fakültesi Dergisi, C.25, S.1, 2017.

Erten, Alev. Türk ve Alman Hukukunda Mesafeli Sözleşmeler (Avrupa Topluluğu Mesafeli Sözleşmeler Direktifi ile Karşılaştırmalı Olarak), Banka ve Ticaret Hukuku Araştırma Enstitüsü Yayınları, Ankara, 2004.

Gezder, Ümit. "Mesafeli Sözleşmeler”, Yeni Tüketici Hukuku Konferansı (Ed. Murat İnceoğlu), 1. Baskı, On İki Levha Yayıncılık, İstanbul, 2015.

Gezder, Ümit. Mukayeseli Hukuk Açısından İnternette Akdedilen Sözleşmelerde Tüketicinin Korunması, 1. Baskı, Beta Yayınları, İstanbul, 2004.

İlgün, Candaş. Tüketicinin Korunması Hakkında Kanun Açıklamalı Gerekçeli, 2. Baskı, Adalet Yayınevi, Ankara, 2015.

İnceoğlu, Murat/Baş Süzel, Ece. "Mesafeli Sözleşme Kurulmasına Aracılık Edenlerin Tüketiciye Karşı Sorumluluğu”, Bahçeşehir Üniversitesi Hukuk Fakültesi Dergisi, C.15, S. 189-190, 2020.

Kalkan Oğuztürk, Burcu. Güven Sorumluluğu, 1. Baskı, Vedat Kitabevi, İstanbul, 2008.

Kara, İlhan. Yeni Kanuna Göre Tüketici Hukuku, 1. Bask1, Ankara, 2015.

Keser, Yıldırım. "Tüketicilerin Kişisel Verilerinin İşlenmesinde Açık Rıza", Selçuk Üniversitesi Hukuk Fakültesi Dergisi, C.28, S.3, 2020.

Sağlam, İpek. Elektronik Sözleşmeler, 1. Baskı, Legal Yayıncılık, İstanbul, 2007.

Topaloğlu, Mustafa. "Madde-48, Mesafeli Sözleşmeler", Milli Şerh, 1. Baskı, Aristo Yayınevi, İstanbul, 2016.

Uzun Kazmacı, Özge. "İnternet Üzerinden Kurulan Mesafeli Sözleşmelerde Tüketicinin Korunması”, Marmara Üniversitesi Hukuk Araştırmaları Dergisi, C.22, S.3, 2016.

Yüce, Melek Bilgin. "E-Ticarette Ayıplı Mal/Hizmet Alan Tüketicinin Hakları ve Bu Hakların Yöneltileceği Muhataplar”, E-Ticaret, 1. Bask1, Aristo Yayınları, İstanbul, 2017.

Zevkliler, Aydın/Özel, Çağlar. Tüketicinin Korunması Hukuku, 1. Baskı, Seçkin Yayıncılık, Ankara, 2016. 